\title{
BETWEEN TESTIMONY AND IRONY: POINTS OF VIEW IN CHERNOBYL PRAYER. A CHRONICLE OF THE FUTURE BY SWIETLANA ALEXIEVICH
}

Keywords: literary reportage, Swietlana Alexievich, point of view, testimony, irony

Słowa kluczowe: reportaż literacki, Swietłana Aleksiejewicz, punkt widzenia, świadectwo, ironia

Chernobylskaya molitva (Chernobyl Prayer) originally came out in 1997 in Belarus. Translated by Keith Gessen, the book was published in the United States in 2005 under the title Voices from Chernobyl: The Oral History of a Nuclear Disaster. The British version, translated by Anna Gunin and Arch Tait, was titled Chernobyl Prayer: A Chronicle of the Future and appeared in the United Kingdom in 2013. In this paper I will try to examine the genre in the book, which is a combination of journalistic and literary discourse. This aspect is important as it determines the focalization. When reading the book we interpret the stories of the witnesses from their point of view but, simultaneously, we perceive the fictional universe through the interpretative frame created by the author.

\section{The illusion of narrative transparency}

Monologues, which constitute the predominant structure of the book, show us the characters whose main role is to tell their stories; ${ }^{1}$ the author's voice seems to be absent. A collection of about forty monologues provides us with the impression of plurality of experiencing Chernobyl, a diversity of styles, and expressions of the horrifying phenomenon. It also creates an illusion of narrative transparency, understood here as the mimetic objective of the reporter who attempts to render the witnesses' spontaneous flow of speech in her narration.

${ }^{1}$ See Sophie Benech, “An Opera with a Chorus,” trans. A. Kaplan, The Nation, vol. 301, issue 24 (2015), 31-32. 
The narration strengthens the impression that it was written down as told; meanwhile, the author gives structure to the accounts she has gathered, edits them (for instance shortens them), and adds her either direct or indirect comments.

That is why, in fact, the focalization in the book is double. The characters (subnarrators) are the main agents who tell their stories, but their monologues are filtered by the main narrator. The referential contract that is present in nonfiction prose ${ }^{2}$ allows us to assume a high degree of congruity between the main narrator and the author. My hypothesis is that in Alexievich's prose we are dealing with a situation as described by Sanders and Redeker, namely that the subject's point of view is embedded in the main narrator's discourse reality. ${ }^{3}$

The presence of an authorial perspective is particularly visible in the metaphorical, often ironic titles and subtitles of the monologues. What is significant is that sometimes the titles and subtitles resemble a summary of the witness' testimony, but in fact they interpret the interlocutor's point of view and create a kind of interference between the voice of the author and the voices of the characters. The main narrator's presence is visible not only in the titles but also in the intertextual strategies used in both the book's prologue and epilogue. This is also implied by the motto of the book.

As I have already mentioned, in Alexievich's narrative the main narrator seems to be barely visible. It is the narrator's deliberate decision to show the subnarrators' point of view as the foreground perspective. Unlike in Secondhand Time, in Chernobyl Prayer Alexievich does not share her own experience; she seems to disappear and concentrates on quoting different sources. In the first chapter she rewrites fragments of Belorusskaya Entsiclopediya, a document that was published by Sakharov Higher College of Radioecology in Minsk:

The Chernobyl disaster released fifty million curies $(\mathrm{Ci})$ of radioactivity into atmosphere, of which 70 per cent fell upon Belarus. Twenty-three per cent of the country's land became contaminated with levels above I Ci $/ \mathrm{km}^{2}$ of caesium-137. For comparison, 4.8 per cent of Ukraine's territory was affected and 0.5 per cent of Russia's. ${ }^{4}$

The predominance of details, facts, numbers, and statistics reveals the writer's attitude, as she wants to create a rational context for the emotional accounts she gathered during her fieldwork. Talking with people has provided profoundly personal stories and gives them a historical perspective: the text gains in credibility.

\footnotetext{
${ }^{2}$ Philippe Lejeune, On Autobiography, ed. Paul John Eakin, trans. Katherine Leary (Minneapolis: University of Minnesota Press, 1989).

${ }^{3}$ José Sanders, Gisela Redeker, "Perspective and Representation of Speech and Thought," in Spaces, Grammar and Discourse, ed. Gilles Fauconnier (Chicago: University of Chicago Press, 1996), 291.

${ }^{4}$ Swietlana Alexievich, Chernobyl Prayer. A Chronicle of the Future, trans. Anna Gunin, Arch Tait (London: Penguin Random House, 2013), 2.
} 


\section{Double focalization}

Let us examine the motto, which is a short yet very important line of the text. The motto, a part of the paratext opening Chernobyl Prayer, was chosen by Alexievich from the works of Merab Mamardashvili. In the following part of the paper I will analyse Mamardashvili's work because, as far as I know, his influence on Alexievich's ideas has never been examined. I believe that Mamardashvili's philosophy is a tool that will help understand the foundations for Alexievich's concept of literature and field work. It can be treated as insight into her point of view.

The motto consists of one sentence: "We are air: we are not earth." The reporter's intentions are to show the air as a medium through which radioactive pollution spreads - which can be dangerous, even deadly. The statement reads like a line of a poem, although it was written by a philosopher. Merab Mamardashvili, born in Soviet Georgia and a graduate of Moscow University, was one of the most important philosophers not only in the former Soviet Union but also in Europe. His intellectual biography is somehow similar to Alexievich's. He was under the influence of Communism and then gradually became more and more skeptical of it. Mamardashvili's biography reveals his ambivalent relations with the Soviet Union. He gave lectures at different institutions in the 1960s, 70s and 80 s, conducted research on Karl Marx's philosophy and then shifted towards continental philosophy based on the fundamental works of René Descartes and Immanuel Kant. Mamardashvili treats Descartes as a source of inspiration for his phenomenology of the object of knowledge and the structure of consciousness. Mamardashvili's concept of the phenomenological Self anticipates the modern, post-ideological Subject, and his paradigm of the object constitutes the 'linguistic' turn in late Soviet Georgian philosophy; therefore, it can be assumed that he shifted - as Alexievich did - from involvement in sovietism towards a philosophy opposed to the propaganda of the USSR. ${ }^{5}$

His philosophy seems to correspond with the main questions raised by Alexievich's journalistic prose; we should bear in mind that philosophy gives a context to her works, ${ }^{6}$ it influences her narrative strategies and the concept of self which is implied by the monologues. ${ }^{7}$ Quoting Mamardashvili reveals

${ }^{5}$ Swietlana Alexievich, Secondhand Time: The Last of the Soviets, trans. Bela Shayevich (London: Fitzcarraldo Editions, 2016), 25.

${ }^{6}$ Agnieszka Wójcińska, Perspektywa mrówki. Rozmowy z reporterami świata [The Ant's Perspective. Interviews with World Reporters] (Wołowiec: Czarne, 2015), 149.

${ }^{7}$ Magdalena Horodecka, "Monologowa forma reportażowa Swietłany Aleksijewicz. Reprezentacja bliskiego Innego w Czasach secondhand" ["The Monologous Form of Svetlana Alexievich's Reportage. Representing the Close Other in Secondhand Time"], Zagadnienia Rodzajów Literackich, no. 2 (2017). 
one of the possible sources of inspiration and is another example of double focalization. We are dealing with Mamardashvili's point of view, but since it is used as a paratext it also suggests that this is the perspective that is important to the author. ${ }^{8}$

Let us recall the philosopher's concepts, which are very close to the main concepts of Alexievich's writings. The similarities are reflected in the preference for oral language, regarded as a tool of thinking. Mamardashvili was called the Georgian Socrates as he developed his own distinctive style of 'philosophizing out loud'. ${ }^{9} \mathrm{He}$ developed a form of dialogical lectures as a main tool of thinking and claimed that hearing a thought can provoke a new thought. He wondered, for example, "How is a new thought possible?"10 Alexievich's assumptions about the effect produced by her journalistic method has the same ideological background. She claims that talking out loud about the most important existential problems is a source of self-consciousness. ${ }^{11}$ Her characters are often presented in the process of or in making an effort to understand their difficult experience. One of the women in the book, the widow of a clean-up worker in Chernobyl, tells the reporter: “'Don't ask. I won't do it. I don't want to talk about it...' (Aloof silence) and then adds: 'No, I will talk to you, I want to understand. If you'll help me'."12

Mamardashvili also asks the following question: How does one think? The philosopher claims that we do not think about our mental processes. The consequences of such a lack of philosophical awareness of our mind and our self are significant, as people act without understanding that their beliefs influence their behaviour. That is why Mamardashvili claims that our consciousness is the most important state of mind human beings should develop. ${ }^{13}$

Mamardashvili's diagnosis is shared by Alexievich - in Russia and in other post-Soviet republics people are unwilling to accept the results of the past ways of thinking. ${ }^{14}$ The Georgian philosopher calls this type of mentality the 'hellish condition' of the society, which seems to be in a state of 'eternal pregnancy. ${ }^{15}$ As one of his disciples points out, the theory of cognition is a part of Mamardashvili's ethics, as he claims that we are responsible for understanding

${ }^{8}$ Gérard Genette, Paratexts. Thresholds of Interpretation, trans. Jane E. Lewin (Cambridge: Cambridge University Press, 1997), 144.

${ }^{9}$ Caryl Emerson, Mamardashvili, Merab Konstantinovich, in Routledge Encyclopaedia of Philosophy, ed. Edward Craig, vol. 6 (London: Routledge, 1992), 68.

${ }^{10}$ Ibid.

${ }^{11}$ Wójcińska, Perspektywa mrówki, 155.

${ }^{12}$ Alexievich, Chernobyl Prayer. A Chronicle of the Future, 213.

${ }^{13}$ Emerson, Mamardashvili, 69.

${ }^{14}$ See Alexievich, Secondhand Time: The Last of the Soviets.

${ }^{15}$ Emerson, Mamardashvili, 70. 
our own minds and observing the implications of our perception of reality, judgements, and choices. ${ }^{16}$

It is remarkable that Mamardashvili developed a theory of aesthetics as well. He often mentioned in his lectures the role of the theatre and novels in awakening attention, memory, and self-consciousness. Most often he analysed Proust. The author of In Search of Lost Time was important to Mamardashvili due to his concept of 'spontaneous memory' and its role in shifting us from a present triviality towards re-experiencing a profound past reality. His notes on Proust are surprisingly similar to the narrative mechanisms employed by Alexievich. Mamardashvili points out:

The text of the novel is the means by which feelings can be experienced. Not those that you experience... but you-as-an-other, recreated, fixed in time and space, posited by a movement of decoding, which does not depend on the chance happenings of life and in which you can establish yourself as a person of fate who controls his own fate. For you there will be no other fate. But that which will be, you already control. ${ }^{17}$

We can observe here the similarity between nonfiction and the novel, whose mechanisms Mamardashvili described in his works. He underlines the role of empathy and imagination, which are active in the subject's mind during the process of reading and entering the role of the character, mirroring our identity. ${ }^{18}$ The mechanism defined by Mamardashvili as "I-as-an-other" is purely hermeneutic. ${ }^{19}$ Remarkably, this theory does not claim that the only genre which can serve as a reflection of self-consciousness is fiction. For this reason, Alexievich's readers can identify themselves with the real people she portrays in her books. It seems that the more individual and personal their accounts are, the stronger the impression of credibility is. The assumption is that the witnesses' speaking about the most important experiences awakes their consciousness, which can be extrapolated to the reader. Here we can observe the mechanism of "I-as-an-other" as described by Mamardashvili and hermeneutics. Bortolussi and Dixon comment on it as follows in Psychonarratology: "Readers by default assume that they will encounter real-life characters and make a concerted effort to fill in the schematic gaps to produce human-like constructs." ${ }^{20}$

${ }^{16}$ See Mamardashvili, Kartezianskie rozmyshleniia [Cartesian Meditations] (Moscow: Progress, 1993).

${ }^{17}$ Mamardashvili, "What is Philosophy?," Voprosii filosofii, no. 5 (1991), 10 (see Emerson, Mamardashvili, 69).

${ }^{18}$ See Anna Łebkowska, Empatia. O literackich narracjach przełomu XX i XXI wieku [Empathy. On Literary Narratives at the Turn of the 21st Century] (Cracow: Universitas 2009).

${ }^{19}$ See Katarzyna Rosner, Narracja, tożsamość i czas [Narrative, Identity and Time] (Cracow: Universitas, 2006).

${ }^{20}$ Marisa Bortolussi, Peter Dixon, Psychonarratology. Foundations for the Empirical Study of Literary Response (Cambridge: Cambridge University Press, 2003), 153. 
This process could be observed during a project conducted by Pracownia Sztuki Społecznej [Social Art Workshop], which was a play directed by Michał Stankiewicz and sociologist Katarzyna Niziołek. The project was called "Prayer. Common Theatre" 21 and it was inspired by Chernobyl Prayer. The directors asked ordinary people to choose one chapter from Alexievich's book, learn it by heart, and then write a short comment, a personal response to the narrative. Then, in a group of 10-15 people they were to publicly recite fragments of monologues and to express their point of view. The method used on stage was purely hermeneutic, it showed how the traumatic experiences of the witnesses were transformed by the readers' perception and how they provoked emotions and thoughts, which were the philosophical questions that came to the minds of the amateur actors and actresses. Let us point out that the experiment involved orality, so it was congruent with the connection Mamardashvili and Alexievich made between speech and consciousness.

\section{Monologues against Homo sovieticus}

Alexievich, who fights against the depersonalised idea of Homo sovieticus and the collective consciousness formed by decades of propaganda, extensively uses the form of monologue to show the individuality of her interlocutors and so as to validate their personal point of view. That is why she does not expose the universal aspects of the experiences of her interlocutors. She describes the particular histories of individual people who faced the catastrophe and its consequences - a catastrophe which was and still is a traumatic experience. The official language of the media when covering the explosion neglected the points of view of individual people and concealed the guilt of the authorities.

Alexievich allows people to use their own voices. This is connected with the two dimensions of the reporter's diagnosis. Chernobyl Prayer is about the responsibility of the Soviet system for the radioactive explosion and about the people who are more or less willing to see their trauma from such a perspective. Thus the diagnosis is of both a political and sociological nature. The narrative tools, which serve to provide the evidence, are as personalised as possible. The author tries to disappear from the text, she exposes the monologues and precisely writes down the personal details of her interlocutors (name, surname, social role, or profession). This shows how important the features of the witnesses are in Alexievich's perspective. The journalist thinks highly of what the Soviet system neglected and disregarded, and the poetics of her narrative is strongly motivated by ethics.

${ }^{21}$ See: http://www.uwb.edu.pl/nowosci/aktualnosci/modlitwa-teatr-powszechny-nowy-projekt-, fundacji-uniwersytetu-w-bialymstoku/c7648aee (acc. 15.05.2017). 
Her voice seems to be absent from the collection of nearly forty monologues of the people she interviewed; however, she admitted to have edited the monologues while writing them down from the audio recording. ${ }^{22}$ She selected the most important sentences or deleted fragments which were not crucial. Her intentions seem to be ambiguous. The subtitle suggests that she tried to write a chronicle. The genre conventions require a precise and detailed account of the present and the past. On the other hand, the monologues of the people who experienced the explosion seem to show a variety of facts, stories about the individuals, and the physical and psychological impact the disaster had on their everyday lives. The reporter is very delicate in dealing with people talking about the boundary situations ${ }^{23}$ they experienced. We are presented with accounts of their relatives dying, accounts of horrible somatic aberrations and the illnesses they have to deal with, and accounts of the loss of lifelong accomplishments. The chronicle shows the past and present of these interviewed people.

Alexievich wants to paint individual portraits of the people she spoke to. She uses narrative tools to present their point of view, but at the same time she tries to recreate their strong spirituality. Religion was a part of human life that Communism tried to eradicate; nevertheless, many people adhered to their religious traditions. Furthermore, they often showed their strong belief in God, the existence of whom was never questioned even after the trauma they experienced. This is another dimension of these individual, very intimate portraits. This perspective is crucial in understanding the importance of the word 'prayer' in the title of the book.

\section{The role of titles and subtitles}

An interpretation of the book seems to be much more complex if we assume that the subtitle of the book does not only refer to the spiritual dimension but also makes an ironic comment. Such a reading is also possible and leads to completely different conclusions. The author is listening to her interlocutors and portrays their individuality but at the same time creates and suggests a dissonance between their observations and her beliefs. Her point of view influences the characters we are listening to while reading their stories. Such an interpretation is based on a fragment that was the source of the title. Alexievich's words are to be found in the last monologue - A lone human voice. This is a very emotional testimony told by a widow, Valentina Timofeyevna, a passage of which reads as follows:

\footnotetext{
${ }^{22}$ Wójcińska, 150.

${ }^{23}$ See Alfons Grieder, "What are Boundary Situations? Jaspersian Notion Reconsidered," Journal of British Society of Phenomenology, vol. 40, no. 3 (2009), 330-336.
} 
How can I go on living? I haven't told you everything, not all of it. I was happy, madly happy. There are secrets... perhaps you shouldn't include my name... People say their prayers in private. To themselves... (Trails off.) No, put my name! It will be a reminder to God... I want to know, I want to understand why we should have to bear this sort of suffering? What's it for? [...].

When he [son - MH] sees me, he asks, 'Where is Daddy Misha? When will he come?' Who else could ask me that? He's waiting for him.

We will wait for him together. I will say my Chernobyl prayer, and he will look at the world with the eyes of a child $[\ldots]^{24}$

The word "prayer" may simultaneously be interpreted as a private, intimate story ("People say their prayers in private") and as a dissenting voice against God or the political system. In the second sense it is ironic.

It seems that such a narrative strategy can be regarded as an example of a homophonic narration. This type of narration was characterised by Mikhail Bakhtin as a special interference of the author's point of view and the character's consciousness. ${ }^{25}$ Another example of such a strategy is to be observed when the reporter includes her interpretation in the monologue. In Alexievich's prose this takes place when the contrast between the system and the individual is not understood by the speaker. In one of the monologues she listens to Alexander Kudryagin, a clean-up worker who makes no comments on the totalitarian aspects of the system. He recollects the orders to clean the roof of the reactor: "Commander says: We will be sending volunteers on to the roof [of the reactor - MH]. Others step out of the line. The prosecutor will be having a word with you." ${ }^{26}$ For Kudryagin, the explosion was one of the most important events in his life, not because it was life-threatening but because it was fascinating - it gave him the chance to prove his heroism. The Soviet system brought him up in the cult of blind heroism and his behaviour proves this power of indoctrination. Being on the roof of the reactor is a kind of uncanny experience, a strong feeling which can cause suicidal thoughts. ${ }^{27}$ For the witness this moment is also connected with experiencing his subjectivity. He recollects:

When I look back on those days... I was there, next to something big, something unimaginable. Words like 'gigantic', 'unimaginable' don't convey it. I felt like - what? (Ponders).

I've never experienced anything like it, even in love. ${ }^{28}$

\footnotetext{
${ }^{24}$ Alexievich, Chernobyl Prayer. A Chronicle of the Future, 292.

${ }^{25}$ Mikhail Bakhtin, Problems of Dostoevsky's Poetics, ed. and trans. Caryl Emerson (Minneapolis-London: University of Minnesota Press, 1984), 21

${ }^{26}$ Alexievich, Chernobyl Prayer. A Chronicle of the Future, 230.

${ }^{27}$ Jacques Lacan, Écrits: A Selection, trans. Alan Sheridan (New York: Norton, 1977).

${ }^{28}$ Alexievich, Chernobyl Prayer. A Chronicle of the Future, 230.
} 


\section{Collisions of the author's and the witnesses' points of view}

Rarely does Alexievich comment on the monologues in an explicit way. As I have already mentioned, she chooses the titles as a place for her interpretation. Sometimes her attitude is also reflected in the witnesses' comments on the reporter's reaction to their testimony. The monologue as quoted above is titled Monologue about freedom, and the irony is obviously striking. Additionally, the text itself is a record of the reporter's astonishment after hearing the interlocutor's words: "It was freedom. I felt myself a free man there... Are you surprised? I can see you are. It is something you can understand only if you were in the war." 29

In her other book, Zinky Boys, Alexievich points out that what she knows collides with the interpretation proposed by the witness, and she shows the witness' point of view. And yet she does not pander to the self-image of the people portrayed..$^{30}$ That is why she rarely asks for authorisation of the interviews. Very often the interlocutor wants to emphasise elements that are different from those the reporter wants to emphasise. Here, again, the philosophical concepts of Mamardashvili prevail - the philosopher tried to comprehend what the difference between our common thought and the moment of creation of a new thought was. He assumed that it required a confrontation between our own opinions and the opinions of others. The process of recalling can either lead to repeating our image of the past or to discovering hidden senses of our behaviour and our motivation. ${ }^{31}$ Quite often, Alexievich is a chronicler of repetition rather than a chronicler of discovery. Irony in the titles and subtitles is virtually the only tool used by the author to distance herself from testimonies that are heavily influenced by ideology.

Another problem with how to verbalise experiences can be observed in Monologue on the need to add something to everyday life in order to understand $i t$. The character wants to understand his traumatic experiences but is unable to do so. The reporter tries to help him by listening and asking him questions, but she cannot alter the witness' point of view. She can only create a situation of speaking about the trauma. This monologue is based on an interview with a photographer who showed her his pictures of Chernobyl. One part of this monologue reflects Alexievich's question, which could have been: "Can you tell me your story?" Instead of answering, the photographer only points to his pictures. The reporter does not give up:

${ }^{29}$ Ibid.

${ }^{30}$ See Alexievich, Zinky Boys. Soviet Voices from the Afghanistan War, trans. Julia and Robin Whitby (London: Norton, 1992).

${ }^{31}$ Emerson, Marmadashvili, 68. 
My story? It's a commentary to go with this... [Points to the photos]. Okay, I will try. Although, you know, it's all here... [Again points to the photographs]. At this time I was working in a factory, and studying history externally at university $\left[\ldots . .{ }^{32}\right.$

The story of his visit to Chernobyl starts and goes on and on. Ultimately, it is built up of words, not pictures, since Alexievich believes that "your story" has to be uttered, "your thoughts" should be expressed out loud. But the final paragraph proves that the photographer was correct, as a verbal representation of his experience is not enough, because there are no words to describe the disaster: "That's my story. Now I have told it. Why did I take up photography? Because words were not enough..." ${ }^{33}$ Such a moment in the narration shows the reporter's ability to give priority to her interlocutor's perspective.

The presence of the ironic tone is very subtle in Alexievich's prose. It is also crucial in order to understand the incongruity of both the author's and the witnesses' point of view. This is particularly palpable in the titles. Let us examine the titles of the book's three main chapters. In the prologue we can observe the emergence of an ironic, bitter tone, and the two subtitles read as follows: A lone human voice and The author interviews herself on missing history and why Chernobyl calls our view of the world into question. The conclusion is: nobody makes an effort to hear the individuals, to ask them about their drama. This is the impact of the Soviet system on ordinary people, and this is why the personal, subjective testimonies that Alexievich collects are so important, as they try to bridge the gap in the system, i.e. create a place for the lone human voice. The irony is hidden in the utopic character of the project's plan. The political consequences are experienced by thousands of people, so the author can only show individual testimonies as opposed to the system which neglected the individual perspective. The author understands the disproportion between the testimonies collected and the voices that are still to be heard. She exposes the roots of the problems with credible representation - they reach the Soviet or post-Soviet media. When we see that the author has to "interview herself," we can easily conclude how critical she was of the local media.

Let us analyse the titles of the three main chapters. The first one sounds close to Eliot's Waste Land (1930). Alexievich constructs a similar metaphor, as she calls the Chernobyl zone Land of the Dead. How should we understand this metaphor and how is it related to the eight monologues presented in the first chapter? First, it shows the artificial nature of the "story about Chernobyl." As one of the witnesses says: "They turned Chernobyl into a factory of horror stories or, rather, cartoons. But it needs to be understood, because we have to

\footnotetext{
${ }^{32}$ Alexievich, Chernobyl Prayer. A Chronicle of the Future, 234.

${ }^{33}$ Ibid., 237.
} 
live with it." ${ }^{34}$ Propaganda makes people search for the truth, which is crucial to "live with it," to survive in the reality after the disaster. There are also people who lost their relatives, but the authorities ("they") deny that Chernobyl was the cause of their death. The land of the dead is also about a political lie:

I want to testify that my daughter died from Chernobyl. But they want us to keep quiet. 'It hasn't been scientifically proved,' they say. 'There isn't enough data. We will need to wait hundreds of years. ${ }^{35}$

The reporter also depicts the trauma that people went through after losing their homes. This is another meaning of the "dead land," namely the destruction of families and patrimonies:

People get here, and they are so happy to stand near their house, near an apple tree in the orchard. First they cry at the graves, then they go to their old houses. And there they cry some more and pray. Light some candles. They lean against their fences as if they were graves. $^{36}$

The above passage comes from Monologue of a village on how they call the souls from heaven to weep and eat with them. What is interesting in the narrative structure is that it is conceived as a collection of short stories. The reporter provides the reader with the names and surnames of the interlocutors: "Speakers: Anna Pavlovna Artyushenko, Yeva Adamovna Artyushenko, Vasily Nikolaevich Artyushenko, Sofia Nikolaena Moroz, Nadezhda Borisovna Nikolaenko, Alexander Fyodorovich Nikolaenko and Mikhail Martynovich Lis." ${ }^{37}$ Sometimes parts of the narration show the tendency to restore the dignity of individuals objectified by the system. In that fragment the journalist's motivation seems to have a different goal. She talked to seven witnesses - four of them women and three of them men - but in this collage of micro-monologues their gender is not revealed. The voices lost their individuality and served as atoms in Alexievich's text. This can be called a monologue-synthesis. A single voice is less important than the voice of the collective, which plays a different role than in individual monologues, as it helps to understand the social dimension of the disaster. The group is represented by ordinary people who do not exactly understand what happened. Their dominant characteristic is that they miss the times when they had access to shops full of sausages or other goods that were absent in different parts of the Soviet Union. This was because their village (Bely Bereg) was located near Chernobyl. They mainly feel nostalgic.

\footnotetext{
${ }^{34}$ Ibid., 44.

${ }^{35}$ Ibid., 46.

${ }^{36}$ Ibid., 56.

${ }^{37}$ Ibid., 46.
} 
The witnesses also make fun of the disaster as this collection of micro-narrations is full of jokes. The title does not fully represent the content of the monologue. Here, Alexievich seems to be particularly attentive to Slavic customs, such as the important role of prayers and graves, which represent a deep connection with the souls of dead ancestors. That is why the reporter emphasises the custom of "eating with souls" in the title, but, surprisingly, there is no mention of eating with souls in the chapter. Once again, the writer's ironic presence is to be felt.

The next chapter, The Crown of Creation, is even more ironic. The title is an intertextual reference to the Biblical book of Genesis. It forms an evident interpretative frame that has been added to the monologues by the narrator. Once again, the irony is strong when we confront the concept of man as the crown of all creatures and the horrible aftermath of the disaster as described in nearly twenty monologues. The interlocutors often think about the impact of the explosion on the environment. The cameraman criticises human ignorance and the dire consequences of the disaster on both the fauna and the flora. According to him, this is a new level of cruelty. There is a moment when he recalls Saint Francis preaching to the birds, treating them as equal partners - a fact that was emphasised by the technician, as Chernobyl for him was an apocalypse of a new kind which tested how humane we truly are, not only towards other human beings but towards other living creatures as well. This is emphasised by Alexievich's decision to use one sentence of the cameraman's long speech as the title of the monologue. It shows the importance of the non-anthropocentric perspective that is present in many of the monologues. The journalist tries to undermine the ancient pride of human beings, who irreversibly destroyed the concept of mankind as a crown of creation:

It is not only about human dimension! We don't want to lower ourselves to the level of animals, the plants, to that other world. But at the same time, man has the capacity to destroy just about everything. We can kill every living thing. It isn't a fantasy anymore. ${ }^{38}$

In Admiring Disaster we are dealing with the problem of the link between Communism and society's reaction to Chernobyl. On the observation that a Russian always wants to believe in something is one of the most representative monologues of this chapter. The interlocutor, a well-educated historian, seems to be an alter-ego of the author, whose opinions as formulated in her books and many interviews we bear in mind. The mutual opinion of both the historian and of Alexievich is as follows: people do not talk about Chernobyl in the context of sovietism. As the man points out: "We are living with the fear. Nature has, as it were, pulled back, waiting." ${ }^{39} \mathrm{He}$ also emphasises the importance of consciousness:

\footnotetext{
${ }^{38}$ Ibid., 126.

${ }^{39}$ Ibid., 209.
} 
"I've thought a lot about these things. Searching for meaning, an answer. Chernobyl was a disaster of the Russian mentality [...] it wasn't just a reactor that exploded but the entire old system of values." ${ }^{40}$ Alexievich also observes that the Soviet mentality is returning. This is why in her other books she uses the metaphor of "secondhand time." In Chernobyl Prayer she pinpoints the main symptoms of the paradox of the "admiring disaster," a strong imperial ambition of the nation believing that it can conquer the whole world, irrespective of having been defeated in the past. The reporter's opinion is also reflected in the historian's monologue:

There's that renowned Bolshevik slogan: 'With an iron first we shall herd the human race into happiness.' The psychology of the rapist. The materialism of the caveman. Defying history, defying nature. And it's still going on. One utopia collapses and another comes to take its place. $^{41}$

Here, once again, we can see the presence of irony, hidden in plain sight in the title and penetrating the witness' voice, the author's porte parole.

Perhaps the most bitter irony is to be found in the subtitle Chronicle of the future. What a paradoxical genre. What is it? It seems that the author has two goals. The first is to ponder on both the past and future of Homo sovieticus. Alexievich clearly tries to portray society's reaction to the nuclear catastrophe as paradigmatic behaviour of the citizens of the Soviet Union. That is why the collected and narrated reactions have the power to shape not only the present but also the future of post-Soviet nations. The horrifying and unpredictable consequences of Chernobyl are in people's bodies and minds.

Another goal of this future-oriented reporter-chronicler is to awaken the consciousness of the reader who should take into consideration the changes brought about by Chernobyl. Alexievich points to the somatic and ecological issues, but she also asks questions about the relationship between human beings and nature. How has our attitude towards the earth, the air, and the fauna and flora changed? She depicts the polluted environment as a source of permanent threat to humanity. On the other hand, she perceives the environment as being threatened by the industrial activity of humans. We have lost our sense of security because of the unprecedented nature of the catastrophe in Chernobyl. Previously, the destruction was brought about by wars and natural disasters, such as earthquakes or floods. Alexievich points out that Chernobyl was a new type of catastrophe. That is why we constantly try to describe what happened or even try to make some prediction, but our efforts seem to be in vain. For this reason, being a chronicler of the future is a paradoxical role - it is both documental and ironic at the same time.

\footnotetext{
${ }^{40}$ Ibid., 210.

${ }^{41}$ Ibid., 212.
} 


\section{Sum mary}

The article is an analysis of Swietlana Alexievich's book Chernobyl Prayer. A Chronicle of the Future and aims to examine its predominant narrative strategies. The author points to the role of monologues, mottos, irony, titles, and subtitles, which help to describe the process of showing the witness' point of view and, simultaneously, Alexievich's interpretation of the gathered data.

\section{MIECZY ŚWIADECTWEM A IRONIA: PUNKTY WIDZENIA W CZARNOBYLSKIEJ MODLITWIE. KRONICE PRZYSZŁOŚCI SWIETEANY ALEKSIJEWICZ}

\section{Streszczenie}

Artykuł jest analizą reportażu Swietłany Aleksijewicz Czarnobylska modlitwa. Kronika przyszłości pod kątem dominujących w książce strategii narracyjnych. Autorka zwraca uwagę na funkcję monologów, rolę mott, konwencję ironiczną, znaczenie tytułów i podtytułów. Celem analizy jest prześledzenie, w jaki sposób w tekście Aleksijewicz współistnieje perspektywa autorska z punktem widzenia świadków, których relacje zostały przytoczone. 